\title{
Peroxy Complex and Crossing Point Temperature of Talcher Coals - An Adducer to Assess the Spontaneous Combustibility Character
}

\author{
P. Behera ${ }^{\#}$ and G. Mohanty ${ }^{\dagger}$ \\ "P. G. Department of Geology, Utkal University, Bhubaneswar-751004, India \\ ${ }^{\dagger}$ Department of Mathematics, Sambalpur University, Burla-768019, India \\ ( ${ }^{\dagger} 703$, Rameswarpatna, Bhubaneswar-751002, India)
}

Received 24 October, accepted in revised form 7 December 2008

\begin{abstract}
Spontaneous combustibility character of the Talcher coals has been measured in terms of peroxy complex and crossing point temperature. Coal samples collected from the two horizons i.e. Karharbari Formation and Barakar Formation were separately studied and the values measured for the aforesaid parameters were recorded. It was found that the coals of this coalfield are highly prone to spontaneous combustion but the coals of the Karharbari Formation show less proneness compared to Barakar Formation.
\end{abstract}

Keywords: Peroxy complex; Crossing point temperature; Spontaneous combustion; Talcher coalfield; Orissa.

(c) 2009 JSR Publications. ISSN: 2070-0237(Print); 2070-0245 (Online). All rights reserved.

DOI: 10.3329/jsr.vlil.1696

\section{Introduction}

Spontaneous combustion of coals is a perennial problem all over the world, but Indian coals in particular show more proneness to combustion characteristic. Talcher being the oldest coalfield in Orissa state are considered highly prone to spontaneous combustion. Due to this problem crores of rupees are being lost in India as coal catches fire and burns automatically.

Earlier Chandra and Prasad [1] studied the coals of the Raniganj coalfield and found that the proneness to spontaneous combustion is related to coalification. They considered different parameters such as crossing point temperature, peroxy index, volatile matter, moisture, petrography etc to draw the above conclusion. The proneness to spontaneous combustion is related to the stratigraphic sequence and the intensity of combustion decreases with the increase in rank. They proposed that this observation might be valid to all coals universally.

\footnotetext{
\# Corresponding author: purnananda.behera@gmail.com
} 
The purpose of the present study is to know whether the coals of the Talcher coalfield fits into the observation of the Chandra and Prasad [1]. For this, two important parameters such as Peroxy complex and Crossing Point Temperature were measured to know their relation to coalification process.

\section{Geology}

The Talcher coalfield covers an area of about 1800 sq.km between $20^{\circ} 50^{\prime} \mathrm{N}$ and $21^{\circ} 15^{\prime} \mathrm{N}$ latitudes and $84^{\circ} 09^{\prime} \mathrm{E}$ and $85^{\circ} 33^{\prime} \mathrm{E}$ longitudes. It comes under parts of dists. Angul, Dhenkanal and Sambalpur. The geological map of the coalfield is shown in Fig. 1.

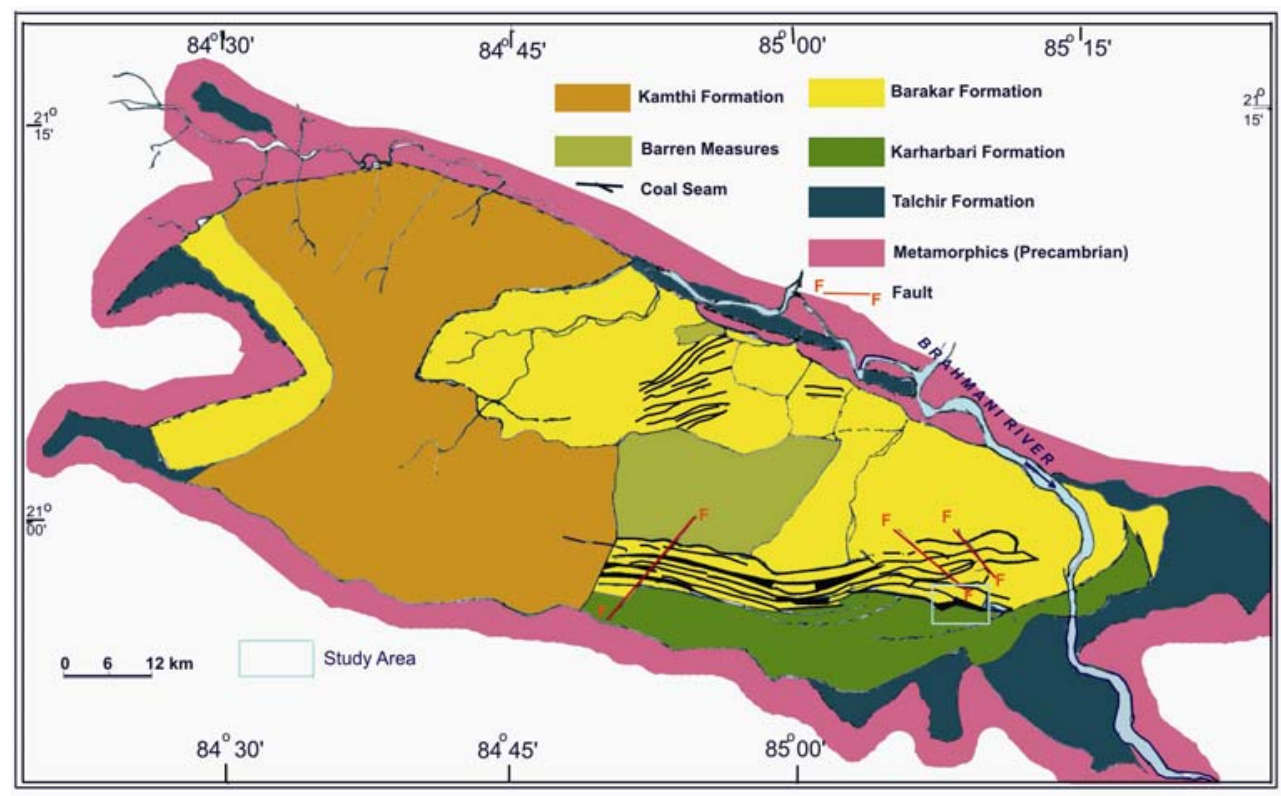

Fig. 1. Geological map of the Talcher coalfield (after Manjrekar et al. [2]).

\subsection{Coal seams}

Coal seams are found in the Karharbari Formation and Barakar Formation of the lower Gondwana group and belong to Permian age. Seam-I occurs in the Karharbari Formation and seam-II to seam-XIII are found in the Barakar Formation. The seam-I varies in thickness from $3 \mathrm{~m}$ to $20 \mathrm{~m}$ and seam-II, $15 \mathrm{~m}$ to $40 \mathrm{~m}$. The different seams are separated from one another by different lithotypes like sandstone, shale, carbonaceous shale, boulders, fireclay etc. The detailed geological succession of the Talcher coalfield is given in Table 1. 
Table 1. Geological succession of Talcher coalfield (after Manjrekar el al. [2]).

\begin{tabular}{|c|c|c|}
\hline Age & Formation & Lithology \\
\hline Recent & & Alluvium and laterite \\
\hline $\begin{array}{l}\text { Upper Permian } \\
\text { to Triassic }\end{array}$ & Kamthi & $\begin{array}{l}\text { Fine to medium grained sandstone,carbonaceous } \\
\text { Shale,coal bands with greenish sandstone,pink clays and } \\
\text { pebbly sandstone at the top }(250 \mathrm{~m}+)\end{array}$ \\
\hline Upper Permian & $\begin{array}{l}\text { Barren } \\
\text { measures }\end{array}$ & $\begin{array}{l}\text { Greenish grey to buff coloured pebbly, coarse to medium } \\
\text { grained highly ferruginous sandstone }\end{array}$ \\
\hline Lower Permian & Barakar & $\begin{array}{l}\text { Medium to coarse grained sandstones, shales,coalseams } \\
\text { with oligomictic conglomerate at the base }\left(500 \mathrm{~m}^{+}\right)\end{array}$ \\
\hline -do- & Karaharbari & $\begin{array}{l}\text { Medium to coarse grained sandstones, shales and } \\
\text { coal seams }(270 \mathrm{~m}+)\end{array}$ \\
\hline -do- & Talcher & $\begin{array}{l}\text { Diamictite, fine to medium grained greenish sandstones, } \\
\text { shales, rhythmites, turbidite etc. }\left(170 \mathrm{~m}^{+}\right)\end{array}$ \\
\hline--- & --- & ---Unconformity--- \\
\hline Precamrian & & Granites, gneisses, amphibolites, khondalites etc. \\
\hline
\end{tabular}

\section{Sample collection and Methodology}

Coal samples of seam-I were collected from five different collieries, namely Dera colliery, Nandira colliery, South Bolanda colliery, Handidhua colliery and Deulbera colliery.

Coal samples of seam-II of Barakar Formation were collected from Jagannath colliery. At one locality of the Jagannath colliery, the seam-II was reported to be fire prone, as such, separate sample was taken from this locality which has been referred to Jagannath fire prone. Deulbera, Dera, Handidhua and Nandira of seam-I are underground mines whereas south Bolanda colliery of seam-I and Jagannath colliery of seam-II are open cast mines.

Peroxy complex is the intermediate oxy-complex formed over the coal surface due to its interaction with the oxygen of air. Yohe et al. [3] and subsequently Jones and Townend [4] observed that ease with which peroxy-complex in coal is formed may help in ascertaining its liability to spontaneous heating. Different analytical procedures were adopted for estimating the peroxy index in coal. Yohe et al. [5]. measured it from its oxidisability by adding excess $\mathrm{TiCl}_{3}$. For determination of peroxy complex, Chalishazar and Spooner method [6] was followed.

Similarly crossing point temperature is the critical oxidation temperature, above which the coal catches fire automatically by absorbing heat and oxygen from air. Coal exposed to air, oxygen gets absorbed on the coal surface and certain fractions of coal substance oxidize with production of some gases (mainly carbon monoxide and carbon dioxide) and water vapour and evolve heat. The oxidation takes place even in normal temperature and humidity but it a slow process and the heat evolved is carried out by air. However, if the rate of dissipation of heat does not keep pace with the rate of generation of heat, the temperature of coal rises. By this process the temperature goes on increasing and reaches a stage of critical oxidation point and then the coal catches fire. This process of self 
heating of coal reaching ignition point is known as spontaneous heating of coal. To measure the crossing point temperature (CPT), the method adopted by Karmakar et al. [7] was followed.

\section{Results and Discussion}

The peroxy complex values of the Talcher coals at room temperature are tabulated in Table 2. The Crossing point temperature values have been recorded in Table 3. Chandra and Prasad [1] did extensive work in the Raniganj coalfield and classified the Raniganj coals as highly prone to spontaneous combustion whose Peroxy Index values were more than $3\left(x 10^{-5} \mathrm{gm}\right.$ equivalent). Since all the coals of the Talcher coalfield showed more than 4.5 ( $\mathrm{x} 10^{-5} \mathrm{gm}$ equivalent) peroxy index (Table 2), the coals of this field was classified as highly prone to spontaneous combustion following the classification adopted by Chandra and Prasad [1].

Table 2. Peroxy complex of coal samples of Talcher coalfield.

\begin{tabular}{|c|c|c|c|c|c|c|}
\hline $\begin{array}{l}\text { No. of } \\
\text { seam }\end{array}$ & $\begin{array}{l}\text { Name of the } \\
\text { sample }\end{array}$ & $\begin{array}{l}\text { Amount } \\
\text { of coal } \\
\text { taken in } \\
\text { grams }\end{array}$ & $\begin{array}{l}\text { Strength of } \\
\text { mercurous } \\
\text { nitrate used } \\
\text { (S) }\end{array}$ & $\begin{array}{l}\text { Ml of } \\
\text { mercurous } \\
\text { nitrate (x) }\end{array}$ & $\begin{array}{l}\text { Equivalent } \\
\text { peroxygen } \\
\text { gm/coal x } \\
\text { S/1000g }\end{array}$ & $\begin{array}{l}\text { Average } \\
\text { equivalent } \\
\text { peroxygen/ } \\
\text { gm coal x } \\
\text { S/1000g }\end{array}$ \\
\hline \multirow[t]{4}{*}{ II } & Jagannath Top & 0.2 & 0.0033 & 3.45 & $5.70 \times 10^{-5}$ & $5.78 \times 10^{-5}$ \\
\hline & $\begin{array}{l}\text { Jagannath } \\
\text { Middle }\end{array}$ & 0.2 & 0.0033 & $\begin{array}{l}3.55 \\
4.43 \\
4.52\end{array}$ & $\begin{array}{l}5.86 \times 10^{-5} \\
7.31 \times 10^{-5} \\
7.46 \times 10^{-5}\end{array}$ & $7.38 \times 10^{-5}$ \\
\hline & $\begin{array}{l}\text { Jagannath } \\
\text { Bottom }\end{array}$ & 0.2 & 0.0033 & $\begin{array}{l}6.32 \\
6.38\end{array}$ & $\begin{array}{l}10.43 \times 10^{-5} \\
10.5310^{-5}\end{array}$ & $10.5 \times 10^{-5}$ \\
\hline & $\begin{array}{l}\text { Jagannath Fire } \\
\text { Prone }\end{array}$ & 0.2 & 0.0033 & $\begin{array}{l}4.06 \\
4.08\end{array}$ & $\begin{array}{l}6.70 \times 10^{-5} \\
6.73 \times 10^{-5}\end{array}$ & $6.72 \times 10^{-5}$ \\
\hline \multirow[t]{9}{*}{ I } & Nandira Top & 0.2 & 0.0033 & $\begin{array}{l}3.55 \\
3.65\end{array}$ & $\begin{array}{l}5.86 \times 10^{-5} \\
6.00 \times 10^{-5}\end{array}$ & 5. $93 \times 10^{-5}$ \\
\hline & Nandira Bottom & 0.2 & 0.0033 & $\begin{array}{l}3.40 \\
3.40\end{array}$ & $\begin{array}{l}5.61 \times 10^{-5} \\
5.61 \times 10^{-5}\end{array}$ & $5.61 \times 10^{-5}$ \\
\hline & South Bolanda & 0.2 & 0.0033 & $\begin{array}{l}5.2 \\
5.15\end{array}$ & $\begin{array}{l}8.58 \times 10^{-5} \\
8.50 \times 10^{-5}\end{array}$ & $8.5 \times 10^{-5}$ \\
\hline & Dera Top & 0.2 & 0.0033 & $\begin{array}{l}3.8 \\
3.8\end{array}$ & $\begin{array}{l}6.27 \times 10^{-5} \\
6.27 \times 10^{-5}\end{array}$ & $6.3 \times 10^{-5}$ \\
\hline & Dera Bottom & 0.2 & 0.0033 & $\begin{array}{l}2.9 \\
3.1\end{array}$ & $\begin{array}{l}4.8 \times 10^{-5} \\
5.1 \times 10^{-5}\end{array}$ & $4.95 \times 10^{-5}$ \\
\hline & Handidhua & 0.2 & 0.0033 & $\begin{array}{l}3.5 \\
3.5\end{array}$ & $\begin{array}{l}5.78 \times 10^{-5} \\
5.78 \times 10^{-5}\end{array}$ & $5.78 \times 10^{-5}$ \\
\hline & Deulbea Upper & 0.2 & 0.0033 & $\begin{array}{l}2.95 \\
3.00\end{array}$ & $\begin{array}{l}4.87 \times 10^{-5} \\
4.95 \times 10^{-5}\end{array}$ & $4.91 \times 10^{-5}$ \\
\hline & $\begin{array}{l}\text { Deulbera } \\
\text { Middle }\end{array}$ & 0.2 & 0.0033 & $\begin{array}{l}2.75 \\
2.80\end{array}$ & $\begin{array}{l}4.5 \times 10^{-5} \\
4.6 \times 10^{-5}\end{array}$ & $4.55 \times 10^{-5}$ \\
\hline & $\begin{array}{l}\text { Deulbera } \\
\text { Bottom }\end{array}$ & 0.2 & 0.0033 & $\begin{array}{l}3.42 \\
3.40\end{array}$ & $\begin{array}{l}5.64 \times 10^{-5} \\
5.74 \times 10^{-5}\end{array}$ & $5.7 \times 10^{-5}$ \\
\hline
\end{tabular}


Table 3. Crossing point temperature of the thirteen coal samples of Talcher coalfield.

\begin{tabular}{ll}
\hline Name of the Sample & Crossing point temperature $\left({ }^{\circ} \mathrm{C}\right)$ \\
\hline Jagannath Top & 138 \\
Jagannath Middle & 145 \\
II Jagannath Bottom & 139 \\
Jagannath Fire Prone & 137 \\
& Average: $139.75^{\circ} \mathrm{C}$ \\
Nandira Top & 144 \\
Nandira Bottom & 150 \\
South Bolanda & 145 \\
Dera Top & 139.5 \\
I Dera Bottom & 146.5 \\
Handidhua & 133 \\
Deulbera Upper & 145 \\
Deulbera Middle & 151 \\
Deulbera Bottom & 148 \\
& Average: $144.66^{\circ} \mathrm{C}$ \\
\hline
\end{tabular}

Crossing Point Temperature (CPT) is considered as one of the important parameters of the coal which classifies the coals as highly prone, moderately prone and least prone to spontaneous combustion. On this aspect many workers have done extensive research all over the world. Work on Indian coals is no less. However, Chandra and Prasad [1] based on study of Raniganj coals, proposed some limits to temperature by which there proneness to spontaneous combustibility could be known. They proposed that coals having CPT above $155^{\circ} \mathrm{C}$ may be considered as safe and least prone to spontaneous combustion, CPT ranging from $140^{\circ} \mathrm{C}$ to $155^{\circ} \mathrm{C}$ as moderately prone and CPT below $140^{\circ} \mathrm{C}$ are highly prone to spontaneous combustion. Here, the results of the Talcher coals show that CPT of seam-I coals vary from $133^{\circ} \mathrm{C}$ to $151^{\circ} \mathrm{C}$, the average CPT for seam-I is $144.66^{\circ} \mathrm{C}$ and coals of seam-II from $137^{\circ} \mathrm{C}$ to $145^{\circ} \mathrm{C}$ and the average is $139.5^{\circ} \mathrm{C}$ (Table 3). Therefore, considering the average value of the samples, coals belonging to Karharbari Formation be considered as moderately prone and coals of Barakar Formation of the Talcher coalfield are highly prone to spontaneous combustion. The fire reported at Jagannath fire prone colliery, may be considered as high risk coals due to its other qualities. Though the coals are grouped as moderate risk coals so far their combustion character is concerned sometimes these moderate risk coals may also catch fire at the timing of mining because several other factors may act as additive reagents to help the coal catch fire. For example, coals of high moisture and low moisture may behave differently even though their CPT range remains same.

\section{Conclusions}

From the foregoing results it is concluded: 
(1) Spontaneous combustibility of coals is related to coalification or rank of the coal. This conclusion which was derived by Chandra and Prasad [1], based on the observation on Raniganj coals is also valid for the Talcher coals. In Talcher coals, proneness to Spontaneous combustion increases with decrease in rank.

(2) According to the classification proposed by Chandra and Prasad [1], Peroxy index more than 4.5 ( $\times 10^{-5}$ gm equivalent) may be considered as highly prone to spontaneous combustion. For Talcher coals, the Peroxy index values exceed $4.5\left(\mathrm{x} 10^{-5} \mathrm{gm}\right.$ equivalent), hence they are highly prone to spontaneous combustion (Table 1).

(3) Chandra and Prasad also proposed crossing point temperature as measurable parameter for proneness to spontaneous combustion. The value of CPT in coals below $150^{\circ} \mathrm{C}$ may be considered as moderate to highly prone to spontaneous combustion. The Talcher coals show CPT value below $150^{\circ} \mathrm{C}$, hence considered as moderate to highly prone to spontaneous combustion (Table 3).

\section{Acknowledgements}

The authors are grateful to Prof. D. Chandra, Emeritus Professor Geology (Retd), Indian School of Mines, Dhanbad, for his fruitful suggestions for the improvement of the manuscript and C. Niyogi, Scientist, C.M.R.S., Dhanbad, for providing the data and samples.of the the Talcher coalfield, Orissa and to Kamal Lochan Mahanta for DTP and editing wok.

\section{Reference}

1. D. Chandra and Y. V. S. Prasad, Int. J. Coal Geol. 16, 225 (1990). doi:10.1016/0166-5162(90)90047-3

2. V. D. Manjrekar, V. N. Choudhary, and K.V. V. S. Gautam, Coal in Geology and Mineral Resources of Orissa, SGAT Publ. 205 (2006).

3. G. R.Yohe and C. A. Harman, J. Am. Chem. Soc. 63, 555 (1941). doi:10.1021/ja01847a055

4. R. F. Jones and D.T.A.Townend, J. Soc. Chem. Industr. 68, 197 (1949). doi:10.1002/jctb.5000680701

5. G. R.Yohe and M. H. Wilt, J. Am. Chem. Soc. 64, 1809 (1942). doi:10.1021/ja01260a017

6. B. H. Chalishazar and C. E. Spooner, Fuel 36, 127 (1957).

7. N. C. Karmakar and S. P. Banerjee, Trans. Mining. Geol. Metallurgical Inst. India 86, 109 (1989). 